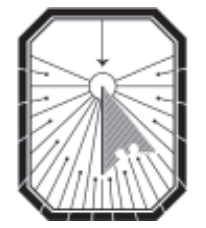

KYIV-MOHYLA

HuMANiTiES JOURNAL

KYIV-MOHYLA SCHOLARLY PEER-REVIEWED JOURNALS

\title{
Ecofeminism in Film Adaptations of Lesia Ukrainka's Forest Song
}

Author(s): Anastassiya Andrianova

Source: Kyiv-Mohyla Humanities Journal 8 (2021): 46-67

Published by: National University of Kyiv-Mohyla Academy

http://kmhj.ukma.edu.ua/ 


\title{
Ecofeminism in Film Adaptations of Lesia Ukrainka's Forest Song ${ }^{1}$
}

\author{
Anastassiya Andrianova \\ North Dakota State University, \\ English Department
}

\begin{abstract}
This article offers a pioneering ecofeminist study of Viktor Ivchenko's Lisova pisnia (1961) and Yurii Illienko's Lisova pisnia. Mavka (1980), two Soviet Ukrainian film adaptations of Lesia Ukrainka's eponymous fairy-drama (1911; Forest Song). It focuses on the interrelated depiction of gender and nature along with the drama's ideological and material aspects: androcentrism and deforestation. The production of both films coincides with, and arguably reflects, what Marko Pavlyshyn describes as "the emergence of a conservationist consciousness" in the USSR in the 1960s. The article's goal is therefore twofold - to bring new ecofeminist insights into Ukrainian film studies and to raise eco-awareness about the Volyn Polissia, which provides the setting for Ukrainka's drama and its adaptations, and currently faces environmental devastation from illegal amber mining.
\end{abstract}

Key Words: Ecocriticism, ecofeminism, Illienko, Ivchenko, film, Lesia Ukrainka.

\section{(2)}

\section{Introduction}

When read as an eco-parable, Lesia Ukrainka's Lisova pisnia (1911; Forest Song) offers valuable environmental lessons about anthropogenic deforestation. Lukash, one of the main characters, makes sopilky (pipes) out of various trees indigenous to Polissia, and along with uncle Lev, builds a hut, settles in, and cultivates the wild forest. In their first encounter, the forest nymph Mavka intervenes to stop Lukash from cutting a birch to taste its sap; later she begs him to use dead (rather than living) wood for construction. When Lukash leaves Mavka for Kylyna, a woman seemingly more capable of reaping and maintaining a household, the balance between the two worlds is upset: Lukash's uncle Lev, a friend of the forest, dies, and Kylyna oversees the felling of the old oak he lived to preserve. Mavka ultimately transforms into a willow tree and is set on fire, along with the ill-fated hut. With the humans expelled, the forest ecosystem is restored. The text's environmental message is shared by Forest Song's many stage and film adaptations, including Viktor Ivchenko's Lisova pisnia (1961) and Yurii Illienko’s Lisova pisnia. Mavka (1980).²

Many thanks to Dmytro Yesypenko (Taras Shevchenko Institute of Literature), the anonymous peer reviewers, and the editors of $K M H J$ for their careful reading and comments.

$2 \quad$ Lisova pisnia, directed by Viktor Ivchenko (Kyiv: Natsionalna kinostudiia imeni O. Dovzhenka, 1961), YouTube, https://www.youtube.com/watch?v=X_VBt6PwNNg; Lisova pisnia. Mavka, directed by Yurii Illienko (Kyiv: Natsionalna kinostudiia imeni O. Dovzhenka, 1980), YouTube, https://www.youtube.com/watch?v=iMutGl8iGyI. 
Although much has been written on nature in Ukrainka's celebrated fairydrama, ${ }^{3}$ to date there is only one ecocritical analysis of Forest Song in print. ${ }^{4}$ In addition to a helpful overview of emerging Ukrainian ecocritical studies, Larysa Horbolis's ecocritical reading confirms the play's relevance to literary ecocriticism; however, it overlooks the depiction of gender and the material conditions of the environment. ${ }^{5}$ The field of ecocriticism remains largely under-researched in Ukrainian studies, both in Ukraine and abroad. ${ }^{6}$ Soviet film adaptations are, moreover, especially underresearched. ${ }^{7}$

This article offers a pioneering ecofeminist study of Ivchenko's and Illienko's Soviet Ukrainian film adaptations by focusing on the interrelated depiction of gender and nature, while highlighting the drama's ideological and material aspects: androcentrism (male-centrism) and deforestation. Ivchenko's conventional approach contrasts with Illienko's avant-garde "poetic cinema." But its abundant nature footage notwithstanding, Ivchenko's film appears less concerned with the environment than Illienko's, which foregrounds the worship and felling of the oak in one of several arboreal scenes; Illienko's film, however, also hypersexualizes Mavka, thereby losing to androcentrism much of what it gains in environmentalism. The production of both films coincides with, and arguably reflects, what Marko Pavlyshyn describes as "the emergence of a conservationist consciousness" in the USSR in the

See Petro Odarchenko, Lesia Ukrainka: rozvidky riznykh rokiv [Investigations from Different Years] (Kyiv: V-vo M. P. Kots, 1994); Olena Ohnieva, Skhidni stezhyny Lesi Ukrainky [Lesia Ukrainka's Eastern Paths] (Lutsk: Volynska knyha, 2007); Olha Turhan, "'Lisovyi kosmos' u drami Lesi Ukrainky 'Lisova pisnia' ['Forest Space' in Lesia Ukrainka's Drama 'Forest Song']," Literaturoznavstvo 1 (2000): 561-65.

4 Larysa Horbolis, "Ekokrytychni vymiry ukrainskoi literatury: dotsilnist i pryiniatnist zastosuvannia (na prykladi 'Lisovoi pisni' Lesi Ukrainky [Ecocritical Dimensions of Ukrainian Literature: The Suitability and Acceptability of Application (on the example of 'Forest Song' by Lesia Ukrainka)]," Filolohichni traktaty 3 (2011): 7-9.

5 The author challenges Horbolis' reading by demonstrating how the projection of human patriarchy onto the forest world mimics and reinforces pernicious androcentric structures (forthcoming).

6 Inna Sukhenko, "From Nature Beliefs to the Politicized Ecocriticism: A Brief Glance on Ukrainian Eco-Imperatives Formation," Visnyk Dnipropetrovskoho universytetu im. A. Nobelia 2.10 (2015): 36.

7 See Stephen Hutchings and Anat Vernitski, eds., Russian and Soviet Film Adaptations of Literature 1900-2001: Screening the Word (London; New York: Routledge, 2005).

8 See Larysa Briukhovetska, "On the Ukrainian Cinematic Tradition, the Dovzhenko Film Studio, and Ivan Mykolaichuk," trans. Marta D. Olynyk, Canadian Slavonic Papers/Revue Canadienne des Slavistes 56.1-2 (2014): 7-16, https://doi.org/10.1080/ooo8 5006.2014.11092752; Vitaly Chernetsky, "The Pleasures and Problems of Leonid Osyka's Zakhar Berkut: Poetic Cinema and Its Limits," Canadian Slavonic Papers/Revue Canadienne des Slavistes 56.1-2 (2014): 43-56, https://doi.org/10.1080/00085006.2014.11 092754; Joshua First, Ukrainian Cinema: Belonging and Identity during the Soviet Thaw (New York: I. B. Tauris, 2015). 
1960s. 9 The role of "politicized ecocriticism" is, in the words of Inna Sukhenko, "to overcome typical social indifference on the part of Ukrainian citizens and cultivate a more active sense of civic responsibility and engagement among the public."1o This article aims, therefore, not only to make a contribution to Ukrainian film studies, but also to raise ecological awareness about the Volyn Polissia, which provides the setting for Forest Song along with its adaptations, and currently faces environmental devastation from illegal amber mining.

\section{Theoretical Framing}

A brief overview of key concepts in ecocriticism (ecological criticism), ecofeminism (ecological feminism), and ecocinema (cinematic ecocriticism) may be helpful, along with a word on adaptation studies. In Cheryll Glotfelty's seminal definition, literary ecocriticism is "the study of the relationship between literature and the physical environment." Lawrence Buell describes the characteristics of environmental texts as follows:

1. The nonhuman environment is present not merely as a framing device but as a presence that begins to suggest that human history is implicated in natural history. [...]

2. The human interest is not understood to be the only legitimate interest. [...]

3. Human accountability to the environment is part of the text's ethical orientation. [...]

4. Some sense of the environment as a process rather than as a constant or a given is at least implicit in the text. ${ }^{22}$

The core idea of ecocriticism is that "human culture is connected to the physical world, affecting it and affected by it"; as a theoretical discourse, it negotiates between the human and the nonhuman [...] expand[ing] the notion of 'the world' to include the entire ecosphere."13 Glotfelty's insistence on a more inclusive meaning of eco follows Glen Love's earlier critique of literary studies' limited humanistic vision which

9 Marko Pavlyshyn, "Honchar's Sobor and Rudenko’s Orlova balka: Environmental Conservation as Theme and Argument in Two Recent Ukrainian Novels," in Slavic Themes: Papers from Two Hemispheres, ed. Boris Christa (Neuried: Hieronymus, 1988), 273. Cf. Sukhenko, "Politicized Ecocriticism," 35, on the development of "ecological aesthetics" in the 1970s-1980s.

$10 \quad$ Sukhenko, "Politicized Ecocriticism," 33.

11 Cheryll Glotfelty and Harold Fromm, eds., The Ecocriticism Reader: Landmarks in Literary Ecology (Athens: University of Georgia Press, 1996), xviii.

12 Lawrence Buell, The Environmental Imagination: Thoreau, Nature Writing, and the Formation of American Culture (Cambridge: Harvard University Press, 1995), 7-8.

13 Glotfelty and Fromm, Ecocriticism Reader, xix. 
prevented scholars from addressing the nonhuman and the broader environmental crisis, urging that they move from "ego-consciousness" to "eco-consciousness."14

Since the early 1990s, literary ecocritics have been putting to practice the claim that "the outside-the-box thought experiments of literature and other media can offer unique resources for activating concern and creative thinking about the planet's environmental future."15 While ecocriticism does not promote any single political agenda, concerns "rang[e] from deep ecology to social ecology, animal rights, and environmental justice. ${ }^{16}$ Commenting, a decade later, on the movement's theoretical and methodological diversity, Simon Estok recalled ecocriticism's original "activist intentions," and invited eco-scholars to ground their literary analyses in a more rigorous theorization of "ecophobia" - "an irrational and groundless hatred of the natural world, as present and subtle in our daily lives and literature as homophobia and racism and sexism." ${ }^{17}$

Ecofeminism combines eco-consciousness with feminism's challenge to patriarchal structures undergirding human societies. It is "a theoretical discourse whose theme is the link between the oppression of women and the domination of nature"18; an understanding of these interrelated oppressions entails that "no attempt to liberate women [...] will be successful without an equal attempt to liberate nature."19 Greta Gaard and likeminded ecofeminists promote "an ethic of responsibilities orcare," identify "theself/otheropposition" and the nature/culture dualism with hierarchy, and emphasize "the fundamental interconnectedness of all life." ${ }^{20}$ While ecocriticism targets anthropocentric assumptions and representations of nature, ecofeminism sees anthropocentrism as a symptom of androcentrism. Exposing man's perceived "right" to exploit nature, what Janis Birkeland calls "Man's ecocidal behavior," is one part of liberation which also involves "changing from a morality based on 'power over' to one based on reciprocity and responsibility ('power to')., ${ }^{21}$ More recent feminist eco-critique has expanded into global and posthuman contexts. ${ }^{22}$

14 Glen A. Love, "Revaluing Nature: Toward An Ecological Criticism," Western American Literature 25.3 (1990): 205-06, https://doi.org/10.1353/wal.1990.0079.

15 Lawrence Buell, Ursula K. Heise, and Karen Thornber, "Literature and Environment," The Annual Review of Environment and Resources 36 (2011): 418.

16 Paula Willoquet-Maricondi, "Introduction: From Literary to Cinematic Ecocriticism," in Framing the World: Explorations in Ecocriticism and Film, ed. Paula WilloquetMaricondi (Charlottesville: University of Virginia Press, 2010), 2. Simon C. Estok, "Theorizing in a Space of Ambivalent Openness: Ecocriticism and Ecophobia," Interdisciplinary Studies in Literature and Environment 16.2 (May 2009): 205, 208, https://doi.org/10.1093/isle/ispo10.

18 Glotfelty and Fromm, Ecocriticism Reader, xxiv.

19 Greta Gaard, "Living Interconnections with Animals and Nature," in Ecofeminism: Women, Animals, Nature, ed. Greta Gaard (Philadelphia: Temple University Press, 1993), 1.

20 Gaard, "Living Interconnections," 2-3.

21 Janis Birkeland, "Ecofeminism: Linking Theory and Practice," in Ecofeminism: Women, Animals, Nature, ed. Greta Gaard (Philadelphia: Temple University Press, 1993), 19.

22 Greta Gaard, Simon C. Estok, and Serpil Oppermann, eds., International Perspectives in Feminist Ecocriticism (New York: Routledge, 2013). This "international" volume features no work on Eastern or Central Europe. 
Writing about ecocriticism's expansion into cinema studies, Paula WilloquetMaricondi defines the emerging genre of "ecocinema" as "films that overtly engage with environmental concerns either by exploring specific environmental justice issues or, more broadly, by making 'nature,' from landscapes to wildlife, a primary focus," along with films that "compel us to reflect upon what it means to inhabit this planet." Ecocinematic critics question the anthropocentric depiction and framing of nature in films "to probe into our values and culturally constructed beliefs about the nonhuman world." ${ }^{24}$ Because of cinema's creation of "the illusion of immediate, direct, and objective access to reality" and its "deceptiv[e] transparen[cy]" as a medium, it is all the more imperative to analyze how cinematic devices frame nature; such framing and representation shape human perceptions, which, in turn, influence "nature by preserving ecosystems or by despoiling them."25

Finally, with regard to adaptation studies, this article follows André Bazin; he has long urged film scholars to search for equivalence, rather than be constrained by a rhetoric of fidelity to either literary originals, to which film adaptations are thought inferior, or cinematic essences - with adaptations, being in principle derivative, thought to fall short of the potential of the cinematic medium. ${ }^{26}$ Heeding Sarah Cardwell's advice, the current analysis understands "adaptation as the gradual development of a 'meta-text' [...] a valuable story or myth that is growing and developing, being retold, reinterpreted and reassessed," approaching texts and adaptations as "points on a continuum as part of the extended development of a singular, infinite metatext," rather than seeing films as subordinate to the literary original. ${ }^{27}$

\section{Historical Background}

In a letter to her mother from early 1912, Ukrainka reminisced about her childhood memories of Polissia, was "reminded of our forests and longed for them" ("ya prosto zghadala nashi lisy ta zatuzhyla za nymy"). ${ }^{28}$ Ukrainka's longing can be described as "solastalgia," which has its origins in "solace" and "desolation" and refers to "the pain experienced when there is recognition that the place [...] one loves is under immediate assault (physical desolation)," "a form of homesickness one gets when one is still at 'home'." ${ }^{29}$ Polissia, Ukraine's "forest belt," experienced deforestation at the turn of the zoth century, around the time Ukrainka composed her eco-drama, in which she

23 Willoquet-Maricondi, “Cinematic Ecocriticism," 9-10.

24 Willoquet-Maricondi, "Cinematic Ecocriticism," 5.

25 Willoquet-Maricondi, "Cinematic Ecocriticism," 7.

26 André Bazin, "Adaptation, or the Cinema as Digest," Esprit 16.146 (July 1948): 32-40.

27 Sarah Cardwell, Adaptation Revisited: Television and the Classic Novel (Manchester:

Manchester University Press, 2002), 25.

28 Odarchenko, Lesia Ukrainka, 133.

29 Glenn Albrecht, "Solastalgia': A New Concept in Health and Identity," PAN: Philosophy Activism Nature 3 (2005): 45. 
featured willows and birches typical of the region..$^{30}$ In the second half of the 19th century, Polissia's population increased by 180 percent due to natural growth and the migration of native and foreign people; as a result, nearly one-third of the forest was cleared for farming. Due to the growth of swamps, forests are now reduced to onethird of the land area. ${ }^{3}$

Ecofeminist literary criticism makes "visible" "previously unnoticed elements" of literary texts. ${ }^{32}$ This reading of two Soviet film adaptations of Lesia Ukrainka's Forest Song brings new light to a widely anthologized text, inviting readers and viewers to think about the deforestation of Polissia during Ukrainka's lifetime; the degradation of air, water, and soil during the Soviet regime; and the amber mining currently marring the region, with its illegal extraction estimated at 300 tons annually. ${ }^{33}$ At the same time, the article points to the significance of womanhood - both Ukrainka's interest in ecological matters and how her women characters bring such issues to the fore. This is warranted because the only ecocritical reading of Forest Song in print fails to consider the role of gender, spotlighting the natural world's ostensible "harmony" and "order,"34 while neglecting the real problems facing Polissia's ecosystem.

In the 1960s and 1980s, when Ivchenko's and Illienko's films were produced, the environment was, in the words of one historian, met with "indifference or ignorance, or both," with daily needs outweighing environmental costs. ${ }^{35}$ Although some discussion of environmental issues was permitted in the Soviet mass media, such as the debate about air pollution in the Baikal-Amur Mainline project following the 1973 decision to revitalize it, ${ }^{36}$ "the sombre reality" of environmental degradation was generally censored, kept secret, and distorted by official channels, as exposed by Boris Komarov in Unichtozhenie prirody (1978; The Destruction of Nature in the Soviet Union), a book that had to be published abroad. ${ }^{37}$ The economic structure of the 1930s, which prioritized industrialization over environmentalism, remained largely unchanged under Khrushchev and Brezhnev, ${ }^{38}$ buttressed by "the Marxist mythology of 'struggle with' and 'conquest of' nature."39 While less visible than in the West, in the

"Polisia," Internet Encyclopedia of Ukraine (Canadian Institute of Ukrainian Studies, 2001), http://www.encyclopediaofukraine.com/display.

asp?linkpath=pages $\%{ }_{5} \mathrm{CP} \%{ }_{5} \mathrm{CO} \%{ }_{5} \mathrm{CPolisia} . \mathrm{htm} /$.

"Polisia."

Greta Gaard and Patrick D. Murphy, "Introduction," in Ecofeminist Literary Criticism: Theory, Interpretation, Pedagogy, eds. Greta Gaard and Patrick D. Murphy (Urbana; Chicago: University of Illinois Press, 1998), 7. international/article/amber-fewer-swept-away-ukraines-northwest-33711.html. Horbolis, "Ecocritical Dimensions," 7. Charles E. Ziegler, "Soviet Images of the Environment," British Journal of Political Science 15.3 (July 1985): 377.

36 Ziegler, "Soviet Images," 369.

37 Boris Komarov, The Destruction of Nature in the Soviet Union, trans. Michel Vale and Joe Hollander (White Plains: M.E. Sharpe, 1980), 44.

38 Ziegler, "Soviet Images," 366.

39 Pavlyshyn, "Honchar's Sobor," 273. 
1960s the USSR did witness, in Pavlyshyn's words, "the emergence of a conservationist consciousness" as a response to the environmental fallout from rapid industrialization and the privileging of production and plan fulfillment over pollution control and environmental legislation. ${ }^{40}$

Deteriorating landscapes and growing concerns over nuclear power notwithstanding, ${ }^{41}$ Soviet Ukrainian critics were cautious or overtly oppositional in their treatment of environmental protection, some denigrating ecologically-minded prose as faddish or "pantheistic." ${ }^{22}$ The literary scandal around the publication of Oles Honchar's Sobor (1968; The Cathedral) and the novel's subsequent omission from standard reference works - until its rehabilitation in 1986 - reveals that even a prominent writer like Honchar could not openly critique industrial pollution. ${ }^{43}$

Ivchenko's film also reflects the movement among Ukrainian filmmakers in the 1960 s to "assum[e] key roles in re-imagining a core Soviet concept - multinationality [bahatonatsionalnist] - shifting its emphasis from incorporation, assimilation and modernization to difference, authenticity and tradition." ${ }^{44}$ This coincided with several screen adaptations of major national theatre performances and those of Ukrainian classics (Franko, Kotsiubynskyi) and contemporary works (Honchar, Stelmakh). ${ }^{45}$ But while a lively and internationally recognized Soviet film scene had formed by the late 1950s, "few in Ukraine or the rest of the USSR wanted to see Ukrainian films." ${ }^{6}$ Starting in 1960, the Oleksandr Dovzhenko National Film Studio in Kyiv, named after the renowned screenwriter and director to highlight its "glorious past," ${ }^{47}$ produced only two or three features in Ukrainian annually; cinema tickets were in Russian, one of many insidious elements which included the presentation and perception of Ukrainian work abroad as Soviet and Russian. ${ }^{48}$ Post-WWII Soviet policy mandated that all films produced outside the Russian Federation be released also in a Russian-language dubbed version, with few exceptions. ${ }^{49}$ The much written-about Serhii Paradzhanov's

$40 \quad$ Pavlyshyn, "Honchar's Sobor," 273. See also: Marshall I. Goldman, The Spoils of Progress: Environmental Pollution in the Soviet Union (Cambridge: MIT Press, 1972);

David E. Powell, "The Social Costs of Modernization: Ecological Problems in the USSR," World Politics 23 (1971): 618-34; Philip R. Pryde, Conservation in the Soviet Union (Cambridge: Cambridge University Press, 1972); Ivan Volgyes, ed., Environmental Deterioration in the Soviet Union and Eastern Europe (New York: Praeger, 1974).

41 Ziegler, "Soviet Images," 376.

42 Pavlyshyn, "Honchar's Sobor," 274.

43 Pavlyshyn, "Honchar's Sobor," 274, 284.

44 First, Ukrainian Cinema, 1.

45 Briukhovetska, "Ivan Mykolaichuk," 10.

46 First, Ukrainian Cinema, 4.

47 First, Ukrainian Cinema, 4.

48 Nadia Kindrachuk, "Eradication of the National Element in Ukrainian Cinema in the 1960s-1970s," Historia i Polityka 24.31 (2018): 116-17, http://dx.doi.org/10.12775/HiP.2018.o15.

49 Vitaly Chernetsky, "Ukrainian Cinema and the Challenges of Multilingualism: From the 1930 to the Present," Journal of Soviet and Post-Soviet Politics and Society 6.1 (2020): 89 . 
Tini zabutykh predkiv (1964; Shadows of Forgotten Ancestors) was exceptional in this regard, deliberately produced in Ukrainian only.50 Paradzhanov's film stars Ivan Mykolaichuk (who would later play Lisovyk and Lev in Illienko's adaptation) and features Illienko's award-winning camerawork.

Ivchenko's and Illienko's adaptations of Ukrainka's fairy-drama include Ukrainian folklore and a uniquely Ukrainian setting; their production can therefore be understood as an important intervention into the history of Ukrainian cinema as well as Ukrainian eco-consciousness. This becomes more obvious when the two films are compared to the short animated Lesnaia pesn (1976; Forest Song), directed by Alla Hrachova based on Mikhail Isakovskii's Russian translation. ${ }^{51}$ Hrachova's Russophone film accentuates the fairy-drama's supernatural elements, especially Lukash's trans-speciation, while removing Lev's character and the felling of the oak with which he is identified effectively silencing the play's ecological message.

\section{Ecofeminism in Forest Song Adaptations}

Viktor Ivchenko's (1912-1972) films have been described as "aesthetically conventional, marked by an aggressive pro-Soviet stance and a linear juxtaposition of right and wrong, without the slightest attempt to allow for ambiguity or differentiation." ${ }^{22}$ His ability to "chur[n] out one box-office hit after another" was due to his "good sense of domestic audiences' tastes and expectations." 53 Due to his background in theatre, Ivchenko's films were also "reminiscent of filmed performances," as is the case with Lisova pisnia (1961). ${ }^{54}$

From an ecofeminist perspective, three elements of Ivchenko's film stand out the frame, the nature sequences, and the use of cross-cutting and interposition, which call attention to the ambiguous status of nature as simultaneously present and (mythically) distanced. The film opens with an image of the drama's prologue, with a voice-over narrating about the beauty of Polissia. The following sequence reveals dense branches gradually clearing into an establishing shot of the forest: creek, marsh, two birds perched on a branch. Lukash (Volodymyr Sydorchuk) and Lev (Petro Vezkliarov) enter in traditional Ukrainian garb, discussing the wonders of the forest as Lukash searches for wood to make a sopilka. Lukash's image is interspersed with glimpses of flora and fauna (swans swimming, a lily blooming) to suggest the Orphic influence of his music on the natural world; this also awakens the wreathed, dark-haired Mavka (Raisa Nedashkivska). As in the fairy-drama, Lisovyk (Forest Elf; Volodymyr Rudin)

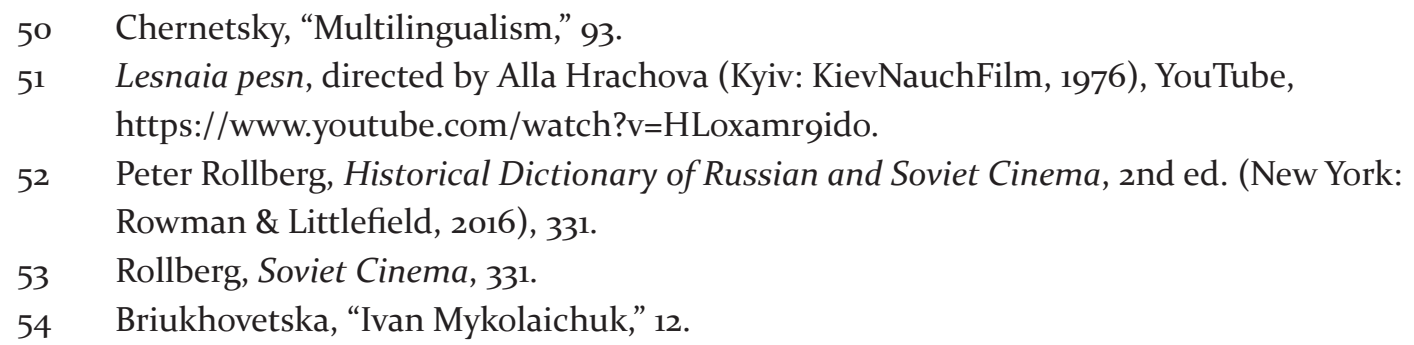


beckons her to avoid humans who take away others' freedom. In their subsequent encounter, Mavka begs Lukash not to cut the birch to taste its sap, which, she insists, is the tree's blood. When she mentions a wild rose, the camera shifts to a wild rose; when Lukash asks what she did all winter while hibernating in the willow, the film switches to a wintry nature sequence; when Mavka asks Lukash to play his sopilka, a floral sequence follows.

The significant thwarting of tree-cutting is subsumed by the swift cross-cutting of nature-themed shots alternating with romantic ones, with appropriately sappy accompaniment: when Mavka and Lukash kiss, leaves and blossoms fall upon them, creating the illusion of snowfall and anticipating the film's (and drama's) final scene of Lukash's death. Scenes of their embrace are interspersed with shots of Polissia branches, blue skies, chirping birds, as Ivchenko transforms the text's natural elements into aesthetically-pleasing melodrama. By foregrounding Mavka, a Ukrainian folkloric figure identified with a characteristically Ukrainian locale, thus conjoining femininity, ethnos, and landscape, Ivchenko's work demonstrates an interest in folklore shared with "poetic cinema"; however, it also unironically plays up the "saccharine" aspects of the discourse of "national [character]" (natsionalnyi koloryt), which "poetic cinema" directors rejected as they "attempted instead to both de-familiarize and re-authenticate a national folklore." ${ }^{5}$

The film's environmental elements are manifested in its women characters. Kylyna (Raisa Pyrozhenko) arrives with black boots slung over one shoulder, traditionally dressed with head covered, in contrast to Mavka, who is barefoot with uncovered loose hair. As Kylyna cuts, Lukash notices her and helps her gather the rye. Whereas Mavka and Lukash first kissed next to a living birch she would not let him cut, he and Kylyna romp amidst harvested rye. The two women are foils: the one represents the forest's pristine spirituality, the other - the materialist conquest of nature. After Kylyna and Lukash leave for the village together, the identification between Mavka and the willow (into which she ultimately transforms) is introduced: a closeup on Mavka's face zooms in on her tears, as she is shown sitting next to a weeping willow by the marsh, and then the camera moves toward the surface of the water to capture several rain drops rolling off of the branches - another instance of Ivchenko's melodramatic touch, coopting the sentimental identification between character and nature to evoke sympathy for Mavka's betrayal.

Spanning shots of the autumnal woods, rich with red and yellow hues, alternate with scenes of Mavka's conversation with Lisovyk, who scolds her for yielding her freedom and then helps her change back into her regal forest robes; with loosened hair, enveloped in light red tulle fabric, Mavka dances from one birch to another, with branches or leaves obstructing the view while also foregrounding the natural elements, serving as a filter between the spectator and the fairy. Mavka's light-colored dress is covered with orange leaves, making her figure indistinguishable from the forest. Although her wardrobe changes are less dramatic than in Illienko's version, the featured 
textiles help solidify her connection to the nonhuman, as does Mavka's wreath, comprised of kalyna (European cranberry, Viburnum opulus).

A series of rapid cross-cutting follows: Lukash and Kylyna's wedding; the forest ravaged by strong winds; Lisovyk cursing Lukash, followed by a wide shot of his transformation into a wolf; Lev's death and burial; saws cutting the old oak under Kylyna's supervision; a wooden cross over a large stump, Lev's sad remains. The subsequent close-up of a wolf howling over Lukash's sopilka zooms in on his eye as it fills with tears; this wakes up Mavka who lies dead inside the rock. Following an explosion with fire and water, Mavka emerges while Lukash is transformed back into human form. Mavka, now in a black dress and a dark greyish-blue tulle wrap, faces Kylyna for the last time, and as the latter curses her, Mavka dissolves into a willow. Kylyna's son cuts from this tree a small sopilka.

The symbolism of the sopilka and the wooden cross is ecologically significant. Both are carved from forest flora by humans: the former is used to awaken Mavka/ nature from her sleep; the latter, used to mark Lev's grave in both adaptations, to commemorate the end of human/nonhuman collaboration. Humanity's reliance on wood for housing and transportation cannot be underestimated; however, in this film, as in real life, this dependence is taken for granted. Lukash's sopilka is used as narrative fodder to transition from flashbacks to the present and vice versa, providing occasions for Lukash to reminisce about his courtship of Mavka (cue romantic music and earlier footage) and ushering in more nature footage: birds chirping; leaves and blossoms falling; Lukash and Mavka's last kiss.

The final scenes of Ivchenko's film are of the frozen Lukash leaning against a tree; of the last page of the text with a voiceover reading Lesia Ukrainka's Forest Song; and of a pair dressed in 196os clothing (Nedashkivska and Sydorchuk), lounging on the grass while reading, which transitions to a closing wide shot emphasizing the expanse of the sky. While the drama's ecocritical elements are transposed from the play to the screen, the addition of the frame distances the narrative proper by presenting it as part of a fictional world, a Polissia filled with anthropomorphic supernatural beings, to be read and contemplated over an idyllic picnic. At the same time, because the reading couple is identical to the drama's star-crossed lovers, played by the same actors, the spectators are also reminded of the text being grounded in Polissia's forest. An ambiguous locus, Polissia is, on the one hand, a mythic/literary image and framing device; on the other, it is a real geographic setting for the frame and narrative proper. The many nature sequences, however, belie the issue of deforestation, while the closing image of a heterosexual couple happily digesting printed material (processed from felled trees!) distracts from the sinister ways in which the forest world mimics human patriarchy (Lisovyk; "Toi, shchov skali sydyt," or "He Who Dwells in Rock"). It is not difficult to imagine how the escapist fantasy of a mythic forest would have appealed to Ivchenko's audience at the start of the decade when Ukraine would emerge "as predominantly urban, only the third Soviet republic to make this demographic shift from a rural and agricultural economy."56 
As adaptations of Lesia Ukrainka's drama, Ivchenko's and Illienko's films are notably different. Both directors worked at the Dovzhenko Studio, but while Ivchenko's conventional melodramatic works were hugely successful, Illienko's innovative productions, which privilege visual associations and psychological insight over plot, were met with less audience approval than his earlier camerawork for Paradzhanov. If Ivchenko catered to the audience's need for melodrama, Illienko (1936-2010) was "a poet-director" whose works "are deliberately involved, even chaotic, frequently switching back and forth between time levels. Visual associations are more important than plot progression or logic, which makes these pictures challenging to viewers"; his camera work "support[s] psychological analysis."57 Visually stimulating and cinematically innovative, Lisova pisnia. Mavka is a belated example of Ukrainian "poetic cinema." ${ }^{8} 8$ By adapting "an ethnographic style of modernist representation," and "seeing themselves as heirs to Dovzhenko and the 'poetic' style of his early films," Illienko and other "poetic cinema" directors thought of their audience differently than their predecessors, addressing their "difficult" films to "an elite and knowledgeable audience," though some were skeptical about the existence of such an audience in Ukraine. 59

At a time when many Ukrainian films were prosecuted and banned by Soviet authorities due to their "Ukrainian bourgeois nationalism," placed on the "notorious shelf" for years, and released to the public only upon Moscow's approval, ${ }^{60}$ Illienko's directorial work did not fare well. His debut as a feature film director, Krynytsia dlia sprahlykh (1965; Well for the Thirsty), a "story of rural decay and subsequent revival," was considered "nationalistic" and only released in 1987; his next project, an adaptation of Gogol's Vechir na Ivana Kupala (1968; On the Eve of Ivan Kupalo's Day) was withdrawn from theaters after a limited release and re-released only twenty years later. ${ }^{61}$ Besides the use of "poetic cinema” techniques, Illienko's casting of Mykolaichuk as Lisovyk/ Lev in his Forest Song reveals the film's ethnographic commitments and a more authentic approach to national folklore than the typical discourse of "national [character]." A famous actor, screenwriter, and the "soul" of "poetic cinema," Mykolaichuk was invested in preserving Ukrainian folk traditions and aware of cinematography's role in such preservation, evident in his acting choices and composition of musical arrangements and screenplays. ${ }^{62}$

Herbert Eagle has argued that, due to its being associatively structured like verbal poetry, "poetic cinema" can "be polysemic, ideologically acceptable and

57 Rollberg, Soviet Cinema, 308-09.

58 In "Poetic Cinema," Chernetsky argues that Leonid Osyka's Zakhar Berkut (1972) is the last major production of the genre.

6o Kindrachuk, "Eradication," 119.

61 Rollberg, Soviet Cinema, 308.

62 Briukhovetska, "Ivan Mykolaichuk," 11-15. 
ideologically dissident at the same time." ${ }_{3}$ Associative linking can be employed through the repetition of objects or "marked" cinematic devices, such as the dozen shots of branches rich with Ukrainian pears in Dovzhenko's Zemlia (1930; Earth), which symbolize the natural cycle and humanity's proximity to nature. ${ }^{64}$ Equally important is the use of montage to evoke certain emotions, a construction that, according to Sergei Eisenstein, "serves to embody the author's relation to the content, at the same time compelling the spectator to relate himself to the content in the same way." ${ }^{6}$ It is through associative structure and montage that "poetic cinema" can create metaphors to convey political and ideological dissonance without being immediately registered or prohibited by censorship. ${ }^{66}$

The "national" content of Illienko's film is evident in the very choice of source material as well as the aforementioned casting of Mykolaichuk; the eco-content is, in turn, revealed in the use of "marked" cinematic techniques: the visual obstructions to the spectators' view of the actors which foreground nature; the added arboreal scenes of oak worship and felling; the stylization of costuming and nudity; the symbolism of the sacrificial fawn; and the authorial/auteur direction of the spectators' gaze. More than Ivchenko's, Illienko's film also evokes an eco-consciousness. It coincides with a more visible environmental debate in the early 1980s, with, for example, the literary critic Viacheslav Palman "reject[ing] the old 'conquest of nature' rhetoric." ${ }^{67}$ Further, juxtaposed with comedic elements, which are absent from the earlier adaptation, is the serious, psychologically evocative use of symbolism, lighting, and color involving Mavka and her (dis)robed body.

Illienko's film opens with a portrait of Lesia Ukrainka that dissolves into the face of Liudmyla Yefymenko as Mavka, with a superimposed wreath and voiceover repeating, eerily, "to die, like a fallen star." In the scene from which this line is excerpted, Lukash wants to kiss Mavka "to death," and lured by romantic sentiment, she admits that death does not scare her: "And yet "twould lovely be / To die as dies a falling star..." (Ni, se tak dobre - / umerty, yak letiucha zirka). ${ }^{68}$ The blending of the two portraits adds an element of autobiographicality, and this can be regarded as a tribute to Ukrainka, also

63 Herbert J. Eagle, "How Poetic Structure Counters Socialist Realist Narrative in Illienko's White Bird with a BlackSpot," KinoKultura 9 (2009), ed. Vitaly Chernetsky, http://www.kinokultura.com/specials/9/eagle.shtml.

64 Eagle, "Poetic Structure," n.p.

65 Sergei Eisenstein, “The Structure of the Film," in Film Form: Essays in Film Theory, trans. and ed. Jay Leyda (New York: Harcourt, Brace \& World, 1949), 168.

66 Eagle, "Poetic Structure," n.p.

67 Pavlyshyn, "Honchar's Sobor," 273.

68 Lesya Ukrainka, Forest Song, trans. Percival Cundy, in Spirit of Flame: A Collection of the Works of Lesya Ukrainka (New York: Bookman Associates, 1950), 202. Lesia Ukrainka, Lisova pisnia, in Vybrane (Kyiv: "Radianskyi pysmennyk," 1955), 475. The play is also available in English translation in Vinshomu svitli / In a Different Light: A Bilingual Anthology of Ukrainian Literature. Translated into English by Virlana Tkacz and Wanda Phipps as Performed by Yara Arts Group, ed. Olha Luchuk (Lviv: Sribne Slovo Press, 2008). 
foregrounding woman authorship, and an evocation of "solastalgia" - as Mavka, like Ukrainka, is about to experience "the pain" of her beloved home (Polissia) coming "under immediate assault." 69

After the opening credits, Lisovyk (Mykolaichuk), draped in animal skins and furs, is shown walking and gazing through the trees at a scene of country life - an observer stance he assumes continually throughout the film. Then a wide shot reveals a procession of villagers with flags and crosses that culminates in a brawl. While the action is focalized through Lisovyk, tree branches between the camera and the scene function both to distance the spectators, creating the equivalent of a theatre curtain, and draw them in by making them, like Lisovyk, part of the forest setting (Ivchenko uses similar obstruction in scenes featuring Mavka). What follows is a shot of a twostory wooden hut being built; Lev (Mykolaichuk), Lukash's mother (Maia Bulhakova), and Lukash (Viktor Kremlov) make their way from this small village to the adjacent forest. Lev cuts some of Lukash's and his own hair along with dry grass and twigs, whispers an incantation, and sets his offering on fire; the next scene shows the three on their knees worshipping the ancient oak decorated with animal skulls. Lukash selfconsciously removes his hat as a sign of respect.

Illienko's adaptation calls attention to the tension between the forest's animism and the encroaching villagers' Christianity, emphasizing what is less obvious in the play. After he learns that Lukash was saved by Mavka from the mischievous "forest folk," Lev concedes that while she has no soul, she has "a good kind heart" " $k$ hoch ty dushi ne maiesh, / ta sertse dobre v tebe").70 Later on Lev quotes his grandfather's wisdom, at once recognizing that pagans are different and encouraging their assimilation: "You only need to know the word, / And you can make a soul the same as ours / To enter into any forest spirit" ("treba tilky slovo znaty, / to y v lisovychku mozhe ustupyty / dusha taka samiska, yak i nasha"). ${ }^{71}$ In Illienko's film, the church procession effectively contrasts the Christian with the pagan worldview, though these boundaries are muddled in the Christological iconography used in Mavka's subsequent selfsacrifice.

By normalizing androcentric arrogance and a domineering attitude toward nature, Christianity, especially in its Western form, has contributed to environmental degradation: "God planned all of [the universe] for man's benefit and rule: no item in the physical creation had any purpose save to serve man's purposes." ${ }^{72}$ Contrary to antiquity's animistic approach to nature, which necessitated placating natural spirits "[b]efore one cut a tree, mined a mountain, or dammed a brook," Christianity brought forth the imperative "to exploit nature in a mood of indifference to the feelings of

69 Albrecht, "Solastalgia," 45.

$70 \quad$ Ukrainka, Forest Song, 209. Ukrainka, Lisova pisnia, 483.

$71 \quad$ Ukrainka, Forest Song, 214. Ukrainka, Lisova pisnia, 489.

72 Lynn White Jr., "The Historical Roots of Our Ecological Crisis," in The Ecocriticism

Reader: Landmarks in Literary Ecology, eds. Cheryll Glotfelty and Harold Fromm

(Athens: University of Georgia Press, 1996), 9. 
natural objects."73 Ukraine's cultural tradition was "deeply attached to the natural world," but following the adoption of Christianity and intercultural encounters with Western Europe, "more detached and destructively materialist attitudes toward nature" displaced the original Slavic nature-centered beliefs; the goal of contemporary ecological ethics is, according to Sukhenko, to restore that balance. ${ }^{74}$ By contrasting Christianity with nature worship - the crosses carried by the villagers, as compared to Lev's oak ritual - Illienko's film underlines the differences between the two worldviews and the important identification between Lev and the oak, which he helps preserve and which dies with him - felled upon Kylyna's order, with the assistance of the forest imps disguised as German (Western) developers. Following the opening scene of tree worship, Lukash and Lev are shown turning a cross-like contraption to unroot a huge fallen tree; the two participate in the clearing of the forest they celebrated only moments before.

An ecofeminist lens illuminates how the film's ecocritical elements are inextricable from its problematic depiction of gender: Mavka is symbolically entwined with the landscape. In one scene, wreathed, she emerges from behind a birch, hides behind another, revealing half of her face on each side of the tree. This arboreal (con) fusion further manifests in her running through the birch grove, wooed by Kuts (Viktor Demertash, the impish source of comic relief) and Perelesnyk ("Willow-o'-the-Wisp," Borys Khmelnytskyi). In the familiar scene that ensues, Lukash tries to cut a birch to drink its sap; Mavka stops him. The camera tracks in a circle. The marked use of stylized costuming and nudity invites ecological and feminist interrogation: Mavka's dresses alternate every few seconds, ranging from white to light beige, some also decorated with green leafage or garlands, all emphasizing the curvature of her body. Earlier, Mavka was shown bathing, with only a sheer crochet wrap, one of many instances of her body being sexualized. Even when she braids her hair and dons ethnic garb (after stripping down), her vyshyvanka (Ukrainian embroidered shirt) is low-cut and revealing. As feminist film theorist Laura Mulvey argues,

The determining male gaze projects its phantasy on to the female figure which is styled accordingly. In their traditional exhibitionist role women are simultaneously looked at and displayed, with their appearance coded for strong visual and erotic impact $[\ldots] .75$

73 White, "Ecological Crisis," 10.

74 Sukhenko, "Politicized Ecocriticism," 33-35.

75 Laura Mulvey, "Visual Pleasure and Narrative Cinema," in Film Theory and Criticism: Introductory Readings, eds. Leo Braudy and Marshall Cohen (New York: Oxford University Press, 1999), 837. For critique, see Mary Ann Doane, "Film and the Masquerade: Theorizing the Female Spectator," in Femmes Fatales: Feminism, Film Theory, Psychoanalysis (New York: Routledge, 1991); Kaja Silverman, Male Subjectivity at the Margins (New York: Routledge, 1992); Constance Penley and Sharon Willis, "Editorial: Male Trouble," Camera Obscura 17 (1988): 4-5. 
In this and other montages, the director's relation to the content, in Eisenstein's words, "compel[s] the spectator to relate himself to the content in the same way." ${ }^{66}$ The camera's "male gaze" accentuates Mavka's sexuality and, by extension, sexualizes nature, setting the feminine and the nonhuman against the masculine and the human; except that the film is focalized through Lisovyk, suggesting that androcentrism is present in Mavka's own culture, which replicates humanity's gender hierarchy. Kuts's and Perelesnyk's pursuits of Mavka further replicate predatorial human male behavior.

Also detailed in the play, ${ }^{77}$ wardrobe is more prominent in Illienko's adaptation than in Ivchenko's. Mavka's white crochet and tulle tunics contrast with Perelesnyk's red flowing shirt. The young Poterchata's (Lost Babes) white tunics stand out against the green marshy background. When spurned by Lukash and longing for death, Mavka is shown in greyish and beige pastels, immersed in mist; her hair down, matted with branches and leaves, her dress ripped and shabby, she wanders through an autumnal landscape, chanting. While she kneels and covers herself with dead leaves, Lisovyk embraces and transforms her into a forest queen: a long black-and-gold gown with an intricate gold wreath and a kalyna necklace, a major plant symbol in both films.

Notable, too, is the different handling of the cutting and reaping scenes to which Illienko adds the poignantly symbolic fawn. In Illienko's film, Rusalka Polova (Field Sprite) and Mavka shed actual blood; Mavka presents her bloodied arm and scythe to Lukash's mother. The latter looks on and judges, like Lisovyk, and the gaze remains "male," albeit "transvestite," 78 meant to affirm the same heterosexist ideals and as invested in human/nonhuman segregation. In the following scene, Kylyna (Liudmyla Lobza) and Lukash roll around in the hay while, at a distance, Mavka hugs a fawn. The next time the fawn appears, it is dead, tied upside down to a stake, and carried by Lukash and his mother as a wedding gift for Kylyna - who embodies nature's anthropogenic destruction more profoundly than in Ivchenko's film or Ukrainka's play. The sight of the sacrificed animal forces Mavka to surrender to doom: she begs "He Who Dwells in Rock," the phantom of death and oblivion, to take her away.

Furthermore, the supernatural is prominent in Illienko's version and provides another occasion for ecocritical insight. Supernatural elements reinforce the human/ nature divide, such as when rejected by Lukash, Mavka crawls back into a willow; on the other hand, they remind the viewers of the human/nature connections, such as when Lisovyk gives Lev a drink (appropriately, in a leaf-shaped vessel) that first

76 Eisenstein, “The Structure," 168.

77 E.g., Ukrainka, Forest Song, 215. Ukrainka, Lisova pisnia, 489. Mavka changes her clothing when Lukash's mother criticizes her forest attire: "a blouse of coarse material, poorly made and patched in places, a scanty skirt and a faded apron" "na yii sorochka z desiatky, skupo poshyta i latana na plechakh, vuzka spidnychyna z nabyvanky i polynialyi fartukh z dymky").

78 Laura Mulvey, "Afterthoughts on 'Visual Pleasure and Narrative Cinema' Inspired by King Vidor's Duel in the Sun (1946)," in Visual and Other Pleasures (Basingstoke: Macmillan, 1989), 33. The female spectator can identify with the active/masculine position, but only as a form of "transvestite" identification. 
transforms him into a young man, then back into his older form, and ultimately puts him to sleep - in a tableau of falling leaves which anticipates that of Lukash's death. Since Mykolaichuk plays both men, figures of authority in their respective worlds, an uncanny effect is created. The unheimlich, in Freud's definition, is "that species of the frightening that goes back to what was once well known and had long been familiar."79 Lev and Lisovyk are doubles, with Lev's meddling role (he brings Lukash and his mother to the forest, teaches Lukash, and oversees his courtship of Mavka) identified with the mysterious and distant Lisovyk (who observes and judges this human meddling). Although Lisovyk closes Lev's eyes in a seemingly peaceful farewell, this gesture can be understood, in psychoanalytic terms, as evocative of "the fear of going blind" that often serves as "asubstitute for the fear of castration." ${ }^{\circ o}$ Indeed, the scene doubles symbolically as (self-)mutilation and (sui)cide because Lev's death ends the collaboration between the human/nonhuman worlds sustained through his lifelong commitment to ecological balance.

The supernatural meets the grotesque in a scene where Kuts interrupts Kylyna and Lukash's pulling of their marriage cart, loaded with her sons and baggage. Kuts makes the load impossibly heavy, making the couple sweat bullets as he lashes them like horses to the sounds of neighing, until Kylyna crashes from exhaustion. This cuts to Lukash's mother and Kylyna supervising a group of men ${ }^{81}$ in black smocks and top hats as they cut down the oak. Impatient with their progress, Kylyna seizes the ax and fells the tree herself, which collapses with a dramatic noise. Leaning against the stump with a self-satisfied grin, she then observes the payment in precious gold turn into worthless wood cuttings. Previously disguised as foreign agents but now in rags, the imps scatter. This scene, absent from the play, at once vilifies Kylyna and makes the forest folk complicit, thereby muddling the human/nature divide and accentuating the forest's darker forces.

As in Ivchenko's film, the scene of Lukash's lupine transformation is dilated for aesthetic effect beyond the few lines it receives in Ukrainka's drama. At the beginning of Act III, "the long-drawn mournful howling of a wolf" is mentioned which "grows louder and louder, and then suddenly breaks off" ("Raptom vse pokryvaietsia protiahlym vovchym vyttiam, shcho rozliahaietsia vse duzhche, duzhche i vraz obryvaietsia"); Lisovyk describes Lukash as "roaming through the woods in wolflike form" ("blukaiuchy v podobi vovchii lisom") and being "nothing but a savage wolf" ("Teper vin vovkulaka dykyi!"); later on Kylyna complains of having to "grub here in the forest like the wolves" ("Skytaiemos po [lisu], yak vovkulaky") in Lukash's absence, a comparison he cannot bear as he forcefully silences her. ${ }^{82}$ Odarchenko considers

79 Sigmund Freud, "The Uncanny," in The Uncanny, trans. David McLintock (London: Penguin Books, 2003), 124.

$80 \quad$ Freud, "Uncanny," 136, 139, specifically, Freud's discussion of "The Sand-Man."

81 Little people were cast in these roles, posing a problematic connection between impishness and dwarfism.

82 Ukrainka, Forest Song, 238-39, 248. Ukrainka, Lisova pisnia, 515-16, 527. 
Lukash's transformation into "a werewolf, a madman" ("vovkulakoiu, bozhevilnym") a failure, because the hero loses his human - presumably superior - identity; ${ }^{83}$ both the drama and Illienko's adaptation support this interpretation, as even the nonhuman Lisovyk evidently looks down upon werewolves, and Mavka rushes out from the underworld to help Lukash morph back into his human self.

Yet, this is hard to reconcile with an animal-centered reading that uncovers in the trans-speciation a transformative experience. Ultimately, Lukash gains enough insight to abandon the human (Kylyna) for the nonhuman (Mavka), though not without hesitation. In Illienko's film, this transformation follows the hero's descent into despair (Odarchenko's "madman"). Lukash is shown climbing by the side of the rock that engulfed Mavka, visibly dreading a woman's muffled voice coming from within. He puts a noose around his neck. Lisovyk pulls the loose end up along with Lukash's body (the noose becomes a leash), and using menacing gestures, instructs him to kneel on all fours and howl. Lukash (still in human form) is then shown with long, disheveled hair, in torn clothes, walking around the birch grove; the scene cuts to Mavka, equally disheveled with grime on her face, wandering around the same apocalyptic landscape. As she attempts to pursue Lukash, he runs away, knocking down birches. Dressed in black, white, and gray, the two meld with the predominantly black-and-white background. Finally, Mavka catches up with Lukash and kisses him, but he withdraws. Through the use of color and lighting, the dark forest figuratively swallows the lovers. Having channeled the beast, Lukash has gone wild. Starkly missing are Ivchenko's luscious flashbacks.

The following dreamlike, at times surrealist, sequence draws on nature symbolism to exaggerate Mavka's heartbreak at the hands of a human, reinforcing her connection to the nonhuman. The intrusion of Christological imagery into a predominantly pagan setting, however, complicates things, as does the film's recurring emphasis on Mavka's sexualized body, which powerfully links woman and nature but at the expense of subjecting both to the male gaze. Mavka rips out and wrings out, from her chest, a red mass mixed with dry grass and flowers; Kuts, in turn, tears this mass, meant to symbolize her heart, from her hand. Then Kuts runs a black horse nearly to death while Mavka observes from behind a tree - in an act that is presumably meant to hurt the humans who rely on this animal for labor, but actually hurts the horse, whose suffering is thus problematically aestheticized. In a heavily reverberating voice, Kuts proceeds to instruct Mavka about Lev's death, pointing to the cross over his grave; the camera shows the band of imps attacking the hut. When Kylyna walks outside to fetch some wood, Mavka meets her with a stern look. Kylyna, mad with laugher, exclaims that Lukash is not there. As Mavka reveals the kalyna branch over her heart, another crucial sequence ensues: from a wide shot of a nude body in the distance to a close-up on Mavka, nude, in a pose resembling the crucifixion, with her genitals covered by flowers, a branch of kalyna placed between her bare breasts. The next image is a closeup of a tree with the same branch; the marked use of kalyna in these shots reiterates 
the simultaneous sacrificial despoiling of woman and nature guided by the auteur's "gaze." Kylyna takes up the ax to cut down Mavka's arboreal form, but Will-o'-the-Wisp intervenes before she can do any damage to the young willow tree, with the following shot exposing everything in smoke and Lukash leaning against the charred walls of the hut. Lukash finds his sopilka among the ashes - the catalyst for remembering and repenting. The scene of human devastation is one of victorious revenge for the nonhuman. Fire symbolizes the renewal of life.

But let us return to the tableau of the nude Mavka. According to John Berger, "[a] naked body has to be seen as an object in order to become a nude." ${ }^{84}$ In European iconography, women are essentialized "because the 'ideal' spectator is always assumed to be male and the image of the woman is designed to flatter him." ${ }^{85}$ The aforementioned use of Christological symbolism is further problematized by scopophilia, the pleasure of looking at Mavka's objectified nude body that the camera extends to the spectators by implicating them in the phallocentric gaze. The spectators are invited to assume a male perspective, which is coded within the film's structure (Lisovyk; Illienko). That Mavka's genitals are concealed under a floral veil ${ }^{86}$ reinforces the dominance of the phallus by marking its absence: her body is symbolically castrated as it is crucified. "The paradox of phallocentrism in all its manifestations," says Mulvey, "is that it depends on the image of the castrated woman to give order and meaning to its world"; the key to this world is the woman's "lack that produces the phallus as a symbolic presence. ${ }^{87}$ Such gendering disrupts the environmental narrative, as the woman's "visual presence tends to [...] freeze the flow of action in moments of erotic contemplation," with the act of fetishization "fixat[ing] the spectator and prevent[ing] him from achieving any distance from the image in front of him." ${ }^{88}$ What Illienko's film gains in eco-consciousness it loses to its sexist depiction of femininity.

Unlike the play, Illienko's version does not close with Lukash's death; the bittersweet awareness of the brevity of human existence as compared to nature's relentless self-perpetuation is conveyed through added scenes. In a closeup on Lukash's face, with his beard and hair already covered with snow, Lisovyk solemnly closes his eyes, echoing the earlier scene with his uncle. He then symbolically helps new life rise from the ashes by sowing some seeds while walking back to the forest past the burnt remains of the hut. The last scene is not of dead Lukash seated by a birch, but of Kylyna, fleeing with her toppled cart. The cycle of nature is suggested in the penultimate scene where Lisovyk hands a sopilka to Kylyna's son, who adopts the elder's tune and might someday return to replay the drama. The film closes with the image of charred ruins disappearing under the snow, its whiteness erasing all signs of human intrusion.

84 John Berger, Ways of Seeing (New York: Penguin Books, 1990), 54.

85 Berger, Ways of Seeing, 64.

86 Flowers are traditionally associated with virginity, deflowering, and rape, as in the medieval Roman de la rose.

87 Mulvey, "Visual Pleasure," 833.

88 Mulvey, "Visual Pleasure," 837, 844. 


\section{Conclusion}

Odarchenko describes Forest Song as "somber, deeply tragic" ("sumna, hlyboko trahichna"). ${ }^{89}$ But from an ecophilic perspective concerned with species and ecosystems, the denouement is more hopeful than tragic despite the protagonists' deaths: it emphasizes the continuation of the forest over the individual sacrifices of its inhabitants (Mavka) and allies (Lev, Lukash). Drawing parallels to the Indian Rigveda, Olena Ohnieva asserts, "the catastrophe at the end of Forest Song is not final, but must be followed by the creation of a new world, a new cosmos." 90 That, added to the brief joy of reuniting with Mavka, explains the "happy smile" ("shchaslyvyi usmikh") on Lukash's frozen face..$^{11}$ Both films cast Lukash's death in hopeful terms, a nod toward nature's persistence.

However, when re-reading the fairy-drama and re-watching its adaptations in the Anthropocene, the current geological age that bears the tangible traces of human influence on climate and the environment, we are reminded that while trees may be a renewable natural resource, they are not inexhaustible. Forests take a long time to regrow, and along with their annihilation comes that of the diverse fauna and flora with which trees share their habitats. That Lukash's sopilky are made from trees indigenous to Polissia highlights the theme of human/nonhuman interconnectedness, but it should also evoke the region's material conditions: over a century ago, when Ukrainka composed Forest Song, and when Polissia experienced deforestation due to human migration and growth; half a century later, when the two adaptations, deliberately or not, brought the environmental concerns of their day to bear upon the original text; and today, when Polissia faces environmental disaster, "a secret war" over fossilized tree resin involving miners, armed gangs, corrupt government officials, and tens of thousands of impoverished villagers..$^{2}$

\section{Bibliography}

Albrecht, Glenn. “'Solastalgia': A New Concept in Health and Identity." PAN: Philosophy Activism Nature 3 (2005): 41-55.

"Amber Fever Swept Ukraine’s Northwest Away." 112. October 31, 2018. https://112.international/ article/amber-fewer-swept-away-ukraines-northwest-33711.html.

Bazin, André. "Adaptation, or the Cinema as Digest." Esprit 16.146 (July 1948): 32-40.

Berger, John. Ways of Seeing. New York: Penguin Books, 1990.

Birkeland, Janis. "Ecofeminism: Linking Theory and Practice." In Ecofeminism: Women, Animals, Nature, edited by Greta Gaard, 13-59. Philadelphia: Temple University Press, 1993.

89 Odarchenko, Lesia Ukrainka, 134.

90 Ohnieva, Eastern Paths, 118.

$91 \quad$ Ukrainka, Lisova pisnia, 539.

92 John Wendle, "The Dramatic Impact of Illegal Amber Mining in Ukraine's Wild West," National Geographic, January 31, 2017, https://www.nationalgeographic.com/ news/2017/o1/illegal-amber-mining-ukraine/. 
Briukhovetska, Larysa. "On the Ukrainian Cinematic Tradition, the Dovzhenko Film Studio, and Ivan Mykolaichuk." Translated by Marta D. Olynyk. Canadian Slavonic Papers/Revue Canadienne des Slavistes 56.1-2 (2014): 7-16. https://doi.org/10.108o/ooo85006.2014.1109 2752.

Buell, Lawrence. The Environmental Imagination: Thoreau, Nature Writing, and the Formation of American Culture. Cambridge: Harvard University Press, 1995.

Buell, Lawrence, Heise, Ursula K., and Karen Thornber. "Literature and Environment." The Annual Review of Environment and Resources 36 (2011): 417-40.

Cardwell, Sarah. Adaptation Revisited: Television and the Classic Novel. Manchester: Manchester University Press, 2002.

Chernetsky, Vitaly. "The Pleasures and Problems of Leonid Osyka's Zakhar Berkut: Poetic Cinema and Its Limits." Canadian Slavonic Papers/Revue Canadienne des Slavistes 56.1-2 (2014): 43-56. https://doi.org/10.108o/ooo85006.2014.11092754.

Chernetsky, Vitaly. "Ukrainian Cinema and the Challenges of Multilingualism: From the $1930 \mathrm{~s}$ to the Present." Journal of Soviet and Post-Soviet Politics and Society 6.1 (2020): 83-102.

Doane, Mary Ann. Femmes Fatales: Feminism, Film Theory, Psychoanalysis. New York: Routledge, 1991 [1982].

Eagle, Herbert J. "How Poetic Structure Counters Socialist Realist Narrative in Illienko's White Bird with a Black Spot." KinoKultura 9 (2009), edited by Vitaly Chernetsky. http://www. kinokultura.com/specials/9/eagle.shtml.

Eisenstein, Sergei. "The Structure of the Film." In Film Form: Essays in Film Theory, translated and edited by Jay Leyda, 150-78. New York: Harcourt, Brace \& World, 1949.

Estok, Simon C. "Theorizing in a Space of Ambivalent Openness: Ecocriticism and Ecophobia." Interdisciplinary Studies in Literature and Environment 16.2 (May 2009): 203-25. https:// doi.org/10.1093/isle/ispo1o.

First, Joshua. Ukrainian Cinema: Belonging and Identity during the Soviet Thaw. New York: I. B. Tauris, 2015.

Freud, Sigmund. The Uncanny. Translated by David McLintock. London: Penguin Books, 2003.

Gaard, Greta. "Living Interconnections with Animals and Nature." In Ecofeminism: Women, Animals, Nature, edited by Greta Gaard, 1-12. Philadelphia: Temple University Press, 1993.

Gaard, Greta, Estok, Simon C., and Serpil Oppermann, eds. International Perspectives in Feminist Ecocriticism. New York: Routledge, 2013.

Gaard, Greta, and Patrick D. Murphy. "Introduction." In Ecofeminist Literary Criticism: Theory, Interpretation, Pedagogy, edited by Greta Gaard and Patrick D. Murphy, 1-14. Urbana/ Chicago: University of Illinois Press, 1998.

Glotfelty, Cheryll, and Harold Fromm, eds. The Ecocriticism Reader: Landmarks in Literary Ecology. Athens: University of Georgia Press, 1996.

Goldman, Marshall I. The Spoils of Progress: Environmental Pollution in the Soviet Union. Cambridge: MIT Press, 1972.

Horbolis, Larysa. "Ekokrytychni vymiry ukrainskoi literatury: dotsilnist i pryiniatnist zastosuvannia (na prykladi 'Lisovoi pisni’ Lesi Ukrainky) [Ecocritical Dimensions of Ukrainian Literature: The Suitability and Acceptability of Application (on the example of 'Forest Song' by Lesia Ukrainka)]." Filolohichni traktaty 3 (2011): 5-10.

Hrachova, Alla, dir. Lesnaia pesn. Kyiv: KievNauchFilm, 1976. YouTube. https://www.youtube. com/watch?v=HLoxamrgido.

Hutchings, Stephen, and Anat Vernitski, eds. Russian and Soviet Film Adaptations of Literature 1900-2001: Screening the Word. New York: Routledge, 2005. 
Illienko, Yurii, dir. Lisova pisnia. Mavka. Kyiv: Natsionalna kinostudiia imeni O. Dovzhenka, 1980. YouTube. https://www.youtube.com/watch?v=iMutGl8iGyI.

Ivchenko, Viktor, dir. Lisova pisnia. Kyiv: Natsionalna kinostudiia imeni O. Dovzhenka, 1961. YouTube. https://www.youtube.com/watch?v=X_VBt6PwNNg.

Kindrachuk, Nadia. "Eradication of the National Element in Ukrainian Cinema in the 196os-1970s." Historia i Polityka 24.31 (2018): 113-21. http://dx.doi.org/10.12775/ HiP.2018.015.

Komarov, Boris. The Destruction of Nature in the Soviet Union. Translated by Michel Vale and Joe Hollander. White Plains: M. E. Sharpe, 1980.

Lawton, Anna. Kinoglasnost: Soviet Cinema in Our Time. Cambridge: Cambridge University Press, 1992.

Love, Glen A. "Revaluing Nature:Toward An Ecological Criticism.” Western American Literature" 25.3 (1990): 201-15. https://doi.org/10.1353/wal.1990.0079.

Luchuk, Olha, ed. Vinshomu svitli / In a Different Light: A Bilingual Anthology of Ukrainian Literature. Translated into English by Virlana Tkacz and Wanda Phipps as Performed by Yara Arts Group. Lviv: Sribne Slovo Press, 2008.

Mulvey, Laura. "Afterthoughts on 'Visual Pleasure and Narrative Cinema' Inspired by King Vidor's Duel in the Sun (1946).” In Visual and Other Pleasures, 29-38. Basingstoke: Macmillan, 1989.

Mulvey, Laura. "Visual Pleasure and Narrative Cinema." In Film Theory and Criticism: Introductory Readings, edited by Leo Braudy and Marshall Cohen, 833-44. New York: Oxford University Press, 1999.

Odarchenko, Petro. Lesia Ukrainka: rozvidky riznykh rokiv [Investigations from Different Years]. Kyiv: V-vo M. P. Kots, 1994.

Ohnieva, Olena. Skhidni stezhyny Lesi Ukrainky [Lesia Ukrainka's Eastern Paths]. Lutsk: Volynska knyha, 2007.

Pavlyshyn, Marko. "Honchar's Sobor and Rudenko's Orlova balka: Environmental Conservation as Theme and Argument in Two Recent Ukrainian Novels." In Slavic Themes: Papers from Two Hemispheres, edited by Boris Christa, 272-88. Neuried: Hieronymus, 1988.

Penley, Constance, and Sharon Willis. "Editorial: Male Trouble." Camera Obscura 17 (1988): 4-5.

"Polisia." Internet Encyclopedia of Ukraine. Canadian Institute of Ukrainian Studies, 2001. http://www.encyclopediaofukraine.com/display.asp?linkpath=pages $\%{ }_{5} \mathrm{CP} \%{ }_{5} \mathrm{CO} \% 5$ CPolisia.htm.

Powell, David E. “The Social Costs of Modernization: Ecological Problems in the USSR.” World Politics 23 (1971): 618-34.

Pryde, Philip R. Conservation in the Soviet Union. Cambridge: Cambridge University Press, 1972.

Rollberg, Peter. Historical Dictionary of Russian and Soviet Cinema, 2nd ed. New York: Rowman \& Littlefield, 2016.

Silverman, Kaja. Male Subjectivity at the Margins. New York: Routledge, 1992.

Sukhenko, Inna. "From Nature Beliefs to the Politicized Ecocriticism: A Brief Glance on Ukrainian Eco-Imperatives Formation." Visnyk Dnipropetrovskoho universytetu im. A. Nobelia 2.10 (2015): 33-38.

Turhan, Olha. "Lisovyi kosmos' u drami Lesi Ukrainky 'Lisova pisnia' ['Forest space' in Lesia Ukrainka’s drama 'Forest Song']." Literaturoznavstvo 1 (2000): 561-65.

Ukrainka, Lesya. Forest Song. Translated by Percival Cundy. In Spirit of Flame: A Collection of the Works of Lesya Ukrainka, 169-26o. New York: Bookman Associates, 1950. 
Ukrainka, Lesia. Lisova pisnia. In Vybrane by Lesia Ukrainka, 438-39. Kyiv: "Radianskyi pysmennyk," 1955.

Volgyes, Ivan, ed. Environmental Deterioration in the Soviet Union and Eastern Europe. New York: Praeger, 1974.

Wendle, John. "The Dramatic Impact of Illegal Amber Mining in Ukraine's Wild West." National Geographic, January 31, 2017. https://www.nationalgeographic.com/news/2017/o1/ illegal-amber-mining-ukraine/.

White Jr., Lynn. "The Historical Roots of Our Ecological Crisis." In The Ecocriticism Reader: Landmarks in Literary Ecology, edited by Cheryll Glotfelty and Harold Fromm, 3-14. Athens: University of Georgia Press, 1996.

Willoquet-Maricondi, Paula. "Introduction: From Literary to Cinematic Ecocriticism." In Framing the World: Explorations in Ecocriticism and Film, edited by Paula WilloquetMaricondi, 1-22. Charlottesville: University of Virginia Press, 2010.

Ziegler, Charles E. "Soviet Images of the Environment." British Journal of Political Science 15.3 (July 1985): 365-80.

\section{(2)}

Anastassiya Andrianova is Associate Professor of English at North Dakota State University. She holds a PhD in Comparative Literature from the City University of New York. Her research is concerned with introducing ecocriticism, animal studies, and disability studies to discussions of Ukrainian and Russian literature. Her publications include the award-winning article "A Postcolonial Reading of Lesia Ukraïnka’s Orhiia" (Modern Drama, 2015); notable, too, is her article "Mavka as Willow: An Ecofeminist Analysis of Lesja Ukrajinka's Forest Song" (forthcoming in Studi Slavistici). 